\title{
We have some reasons to be proud of Accounting in Brazil
}

Natan Szuster

Universidade Federal do Rio de Janeiro, Faculdade de Administração e Ciências Contábeis, Rio de Janeiro, RJ, Brazil

E-mail: szuster770@gmail.com

\section{INTRODUCTION}

Thanking for the opportunity to be the author of this Editorial, I aim to bring comments on aspects I have learned over the forty years of experience in the world of Accounting. Many of the points raised reflect thoughts, lectures, and very intelligent readings I have had the opportunity to access within this period.

A fact of great importance, which led me to never walk alone was my entry to the University of São Paulo (USP). Between 1978 and 1985, attending the MA and Ph.D. programs, I met professors and classmates of enormous technical knowledge, ethical and human greatness, who built the firm foundation of the Department of Accounting and the Institute for Accounting, Actuarial, and Financial Research Foundation (FIPECAFI), based on professor Sérgio de Iudícibus' inspiration. An example for research is checking the chapter on Accounting Principles in the book Análise de balanços [Balance sheet analysis], published in 1977, i.e. 38 years ago. The depth, clarity, and intelligence are remarkable. The concepts introduced are valid and profound to the present day. Certainly, the USP has changed Accounting in Brazilian for better.

Due to contact with this significant group, I had the opportunity to participate in relevant moments. I highlight the study and application of the Integral Monetary Correction method at the hyperinflation time, the adaptation of Accounting to the various economic plans and also the convergence of Accounting to international standards, first the United States Generally Accepted Accounting Principles (USGAAP) and later on the International Financial Reporting Standards (IFRS). A remarkable fact was the adaptation of the Brazilian regulation to that issued by the International Accounting Standards Board (IASB), a process that has been developed very effectively despite its great complexity. A very important merit must be assigned to the members of the Brazilian Accounting
Pronouncements Committee (CPC), highlighting the work conducted by professors Eliseu Martins and Nelson Carvalho, who played the role of architects and strategists, defining through scope the Consolidated and Individual Financial Statements, as well as the individual ones, and the role of diplomats, in the relation with government institutions, especially the Department of Federal Revenue of Brazil. This is a remarkable work that definitively amends Accounting in Brazil.

A remarkable fact is the expansion of MA and Ph.D. courses in Accounting in Brazil. We must recognize that the Department of Accounting was crucial, as professors in the various Brazilian states graduated from USP or studied with professors who have studied in São Paulo. The great pioneers created followers who spread their thoughts throughout the country.

In the teaching craft, I also had the opportunity to experience the change that took place due to transformations in society and economic operations, through significant changes in Accounting and what is expected from those who will pursue the profession. The greater demand for knowledge, along with the need to judge things, working in multidisciplinary teams, in addition to the globalization of companies, triggered relevant changes that are still in process. At all levels, from the very first day of classes, professor and student must be aware of the need to be attentive to constant changes and of the understanding that, in order to master Accounting, there is a need to have a great capacity and discipline, supplemented by the need to obtain knowledge from the various related sciences, as well as from the business world. Technological advancement is a challenge and a great ally.

Based on this experience and trying to act as an observer of the evolution of Accounting within this period, I make some comments I regard as useful for reflection.

\section{IMPORTANCE OF ACCOUNTING}

A fact is a great certainty. The importance of Accounting for everyone. The statement I use in the beginning of my lectures, "Accounting is a Human heritage," represents a big truth and I believe it will never change.

Accounting always boosted the development of society by controlling economic operations and the generation of information making organizations possible, enabling mediation between different interests. Its performance in the business field, government entities, and nonprofit entities is grounded in the pressing need to think through reality with a faithful representation and relevance for the various users of information.

As shown in the IASB's mission, the standards developed aim to provide transparency, accountability, and efficiency to financial markets worldwide. And the regulation serves the public interest, by fostering trust, growth, and long-term financial stability for the global economy. Thus, through accounting information, it is 
possible to reduce uncertainty and, as a consequence, lower the cost of capital in order to look for increasing the living standard of people. There is a critical importance for companies whose performance may affect the lives of thousands of people, e.g. financial institutions, electric companies, water supply companies, and health care companies.

A relevant aspect is grasping a forward-looking view of Financial Statements. Accounting has to be seen as a science that not only depicts the past, but mainly aims to enable users to extract information of the future. Accounting always experiences significant changes, as they have to reflect all economic events and phenomena that affect the property of all entities in the world, which develop new ways of operation on a daily basis.

As a knowledge field, we observe its great beauty, especially with the prevalence of the economic substance over the legal form that requires duly reasoned judgments. The study of accounting issues, deepening concepts and also doing exercises, such as, e.g. preparation of Consolidated and Individual Financial Statements greatly improves reasoning. Learning the accounting model based on the double entry method allows the professor to develop a teaching method that encourages everyone. This fact may be evaluated by reading the text published in Revista FIPECAFI, no. 3, entitled "Um novo instrumento para aplicação na Contabilidade" [A new tool to apply in Accounting]. Some understanding of the various phases of a complex economic transaction may be obtained in a safe way. The subsequent translation into accounting language is a very interesting intellectual activity, which requires great application of knowledge, because it requires a firm foundation in several fields of knowledge, in addition to the existing standards. The analysis to define the accounting recognition of a stock purchase, a leasing operation, a grant of stock options requires some knowledge of business fundamentals and the related legislation. In this process, we learn on a daily basis. The breadth of issues that arise every day is surprising and Accounting has to find an useful answer considering its mission of generating information for decisions making.

And because Accounting is a social science, the same event may have different accounting interpretations, if it is duly justified. As a result, it is feasible to understand the lengthy period of time required to develop a standard. It is interesting to notice that every professional may have various perceptions when depicting the same reality, notwithstanding the existence of accounting theory and the regulation related to it. In certain situations, a great intellectual capacity is required so that others are convinced of our position regarding a given topic. Since graduation from college, the mental model, the group to which we belong, and culture can influence the views of people as for our positioning with regard to a given transaction.

Another important factor is the need to have a broad knowledge of activities. An accounting practitioner shall learn the full operation of the sector where she/ he will work, ranging from its legislation to its structural functioning. Especially when there are specific standards, such as, e.g. in any government or financial activity, in the insurance, electricity, or other industry of great economic importance. Even to understand the Financial Statements of a football club a firm foundation is needed. Knowledge has to be extended to seek some understanding of the transactions and the ability to dialogue with operational teams. For instance, to set an accounting policy for financial operations, property, or intangible assets in the various entities there is need for a broad knowledge of the origin of their respective economic transactions.

Finally, the fact there is an aspect regarded as negative, the so-called "earnings management" reflects the reality that accounting information is extremely important and that, according to the constitution of the human, the latter is likely to use her/his knowledge to achieve her/his goals by increasing or decreasing the value of an accounting element. The relevant factor is that the higher the quality of accounting regulation and the role played by regulators, the tendency is reducing the opportunity to make something harmful to one or more groups of economic agents.

\subsection{Usefulness}

A key factor in Accounting represents its great practical use, as it constitutes an activity that provides services to the entire society.

A significant aspect that has a relation with economic and also moral facts is the so-called Accountability, generally translated into Portuguese as "Prestação de Contas" [Statement of Accounts]. We must consider that it is really an act of justice that managers demonstrate what was accomplished with the resources provided to them, through the concept of stewardship. This fact is particularly relevant to the Government and its entities, non-governmental organizations (NGOs), and public companies, but it is also of importance to all entities that are embedded in society. A viewpoint is that there can only be safety and democracy with transparency. And Accounting is the main tool that society has to carry out the process of statement of accounts in economic terms, as well as to evaluate it.

The disclosure of periodic Financial Statements is a key milestone in the life of a company. As a result of technological advances, it is possible that in the future Financial Statements are evidenced in an even more timely way. Grasping the economic, financial, and property status through a joint view of all Financial Statements is core to all users. Each information in the Financial Statements is important, but it should be taken into account that the book value information, with its varied unfolding, which is linked to the analysis of Comprehensive Profit represents a basis for evaluating the success of a company and a very important parameter to remunerate those participating in the result, such as shareholders and employees. The latter group cons- 
titutes a relevant user, which ideally should think as if it was a company's partner, grasping the role, its challenges and potentials, as well as the difficulties faced. A recent evolution is the position that information on Cash Flows of a company is accounting information. The reconciliation between profit and cash is key information provided by Accounting. A proposal might be that the companies, optionally, also started providing disclosure of the Operational Cash Flow according to the Direct Method. Something very important is the Value Added Statement, which enriches the information set.

A complex issue is the relation with the taxation aspect, which constitutes one of the largest expenditure items in a company. An accounting practitioner has to try knowing the legislation and grasping the tax consequences, despite the great difficulty. A major challenge is seeking to emphasize the importance of accounting information in small and mid-sized companies that focus on the fiscal aspects. In this case, the professional should, being aware of the owners' needs for fiscal purposes, demonstrate the importance and potential of informative capacity, a noble stage of our work. We must demonstrate that all entrepreneurs have much to gain by using accounting information in decision making. Accordingly, we must see as normal the existence of certain differences between the accounting criteria and fiscal legislation; and the company, through accounting information, must make adjustments to suit the legal requirements. A relevant fact is providing information with a quality that meets the expectations of all users, including internal users. The latter should use accounting information as a reference; such a fact brings a number of benefits. Using the same parameter that the market adopts to analyze the company is very important for an objective internal evaluation. In managerial terms, there is great capacity of use for planning and controlling " $\mathrm{Da}$ tabases" that combine monetary information and non-financial values and parameters.

Another relevant factor is the capacity of a company to mitigate the risk of loss of assets. The importance of a corporate governance structure grounded by means of the "internal control system" to protect property is crucial. Accounting constitutes the great base generating the track so that all issues can be confirmed and deepened. In this case, there is the great use of the capacity provided by the evolution of Information Technology (IT). A relevant fact that constitutes a case study was that involving PETROBRAS, with disclosure from the second half of 2014. This company, which has an excellent technical staff, underwent big losses due to corporate governance problems. Accounting has demonstrated its importance as the science that allowed estimating in monetary terms the losses incurred. The need for Audited Financial Statements was highlighted by all sectors of society as a primary element for regaining trust in the company. And an undeniable fact is that a deepening of facts will become feasible by using the potential offered by the accounting practice that reproduces the memory of facts.

\subsection{Points for Reflection}

A fact we have to recognize is that, despite the many advances made in recent years, there are still many points for improvement in the accounting regulation. We introduce some aspects for analysis.

A point which demonstrates the extreme complexity of Accounting is the discussion of its Conceptual Structure. It is interesting how an ancient science debates crucial concepts such as the definition of elements in the Financial Statements. An example of the complexity is the distinction between liabilities and equity for certain compound and hybrid financial instruments. Another aspect that may be regarded as frustrating derives from the difficulty of a consensus between the two regulatory entities (IASB and the Financial Accounting Standards Board (FASB)). As a result, the possibility to have two Conceptual Structures is a practical difficulty. However, we have to understand the fact by considering the complexity to establish universal accounting standards applied to all sectors of the economy. An example is the difficulty in setting the criterion for the establishment of Estimated Losses on Accounts Receivable. The use of the concept of Expected Loss has many merits, but it allows a possibility of revenue management. Adopting the concept of Effective Loss also has many drawbacks.

It must be emphasized that companies should strictly comply with the Accounting Pronouncements for the disclosure of Financial Statements. Applying the Accounting regulation is crucial for the safety of everyone. However, a pathway that may be followed for improvement is increasing supplementary information. The proposal is that such information is optional just in order to provide the company with freedom to use a differential procedure, and judgment must be made by the various users. The optional application can stimulate the concept to be subsequently applied by regulation.

A primary aspect is addressing the accounting measurement through currency. This point was raised by professor Eliseu Martins in his blog in the magazine Capital Aberto in March 2015. Indeed, it is a matter of great significance, since Accounting has great usefulness due to the quantification of various events bonded in a monetary language. This fact makes Accounting unique - it is the universal language of business. However, a key factor is recognizing that the monetary unit has not a constant purchasing power and that this fact should be taken into account during the preparation and analysis of Financial Statements so that they are fully useful for decision making. There must be great care to avoid monetary illusion, which can be extremely harmful. The optimal solution might be deploying the Integral Monetary Correction method, which was adopted in Brazil on a mandatory basis for public companies between 1987 and 1995 . The fact the inflation rate has decreased after the Plano Real [Real Plan] does not constitute a definitive factor to prevent the method to be applied. A core aspect is observing that, with the current inflation rates, the benefit of its application in managerial terms must overcome the 
cost, and the ideal option might be disclosure to external users. A possibility might be using the Integral Monetary Correction method at least when communicating specific information, such as, for instance, the disclosure of financial expenses and revenue gains in actual terms, i.e. the actual impact less the inflation rate.

A fact related to measurement refers to the application of the concept of Fair Value. This concept is very complex, subjective, but its application certainly increases the informational capacity of Accounting, when compared to the cost method. A relevant aspect is that Fair Value is useful to be included in the Equity Balance Sheet on a specific date, but at the moment it does not provide comparisons at constant currency between two periods. Thus, the ideal option to be sought is Fair Value applied through the Integral Monetary Correction method. This aspect would also be very important for improving operations in accordance with the Current Value.

Another very complex point refers to the accounting processing that derives from exchange rate fluctuations. The adoption of floating exchange rates generates substantial variations, which may have a temporary nature and be reversed afterwards. A problem is that the company has to necessarily update the monetary items in foreign currency and it cannot update its non-monetary assets, which in some cases have a link to the foreign currency or they underwent significant variations in terms of current cost. This fact contributes to a loss in the quality of accounting information. The method of translating Financial Statements through the concept of Current Dollar is also an item that may be improved.

This problem of asymmetry between assets and liabilities has an impact on companies that acquire assets to pay in installments. This case is very relevant to public service concession holders.

An always debated point refers to the accounting processing of internally formed intangible assets. It is understood that the current accounting regulation is correct. However, the proposal is that if a company has non-book valuable intangible assets should highlight this fact in supplementary information.

Another breakthrough regarding disclosure is the Integrated Reporting as a communication tool. Its adoption constitutes a major instrument that bind a company to society. A major effort should be made to expand its practical application.

Checking the agenda of regulatory entities, we observe the proposal of many amendments that reflect changes in the economy and also greater knowledge of all those involved in the process. In terms of accounting research, a proposal is that it is developed regarding the priority topics being studied by the IASB considering working groups to contribute to this evolution. An example might be conducting studies that analyze the new standards on Revenue Gains, Financial Instruments, and Leasing. The need to investigate user's knowledge is so remarkable that the very standardizing and regulatory entities have been conducting research.
It has been shown that there is a high possibility of innovation in Accounting and there may be numerous applications contributing to the public hearings of the IASB. An example is the Special Asset classification method introduced in chapter 6 of Manual de contabilidade societária [Corporate accounting manual], a book that is a matter of pride for all accounting practitioners in Brazil. Another example of a major initiative was the preparation of the Statement of Value Added, which has as its reference studies by professors Ariovaldo dos Santos and Nelson Carvalho. We, Brazilians, must make an effort so that users from other countries start grasping the importance of this statement.

\subsection{The Accounting Practitioner}

In the book Contabilidade e finanças no Brasil [Accounting and finance in Brazil], published in 2012, on page 17, professor Eliseu Martins asks this question: "But, eventually, what do we want from Accounting and an accounting practitioner, good quality information or just compliance with rules?"

The purpose of the text was emphasizing the fact that an accounting practitioner should work in order to generate good quality information by using her/his judgment ability and avoid being restricted to comply with the rules set. In Brazil, we observe this is a gradual evolution, but there is a need for great support of administrators and, particularly, independent audit professionals and regulatory entities.

The fact is that the role played by a professional in a company is very wide, as the professional is a great administrator of resources, including the human ones. There is a great relation to the well-known IT. Joint knowledge covers the architecture of a system that starts by preparing the Accounts Plan, in order to achieve the goal of generating useful information for external and internal users in the end of the process, moving across the company as a whole. The evolution deriving from enterprise resource planning (ERP) has changed the conception of a very dynamic professional practice, because the recognition process takes place in the many areas within a company. This process generates agility, but it constitutes a risk that must be constantly monitored by accounting practitioners.

The accounting practitioners who work in the field of reports, which covers the preparation of Financial Statements, must have great expertise regarding the operations. Writing the Explanatory Notes is an intellectual process that must evolve to focus on the disclosure of relevant information. The professional must try to be objective and even inform facts that may not be positive for the company, but they are significant to the user.

At this point, a major evolution is expected in accounting disclosure; a point that was triggered by the issuance of the CPC Guidance 07 - "Disclosure in the Accounting and Financial Report with a General Purpose," in 2014. The Brazilian initiative was highly praised by international entities and it constitutes a definitive pathway. 
Therefore, the professional, on her/his daily practice, must have great awareness to safely apply the concepts of materiality and cost-effectiveness ratio. This work requires an enhanced capacity for innovation and why not using the term "creativity", despite the misun- derstanding related to this word when linked to Accounting? This is an unfair fact with regard to our profession. Inter-relationship and exchange of experiences between professionals and scholars is crucial for both of them.

\section{FINAL REMARKS}

By analyzing the current Accounting in Brazil, we may be proud of the great masters that made it possible we could have internationally known studies and adopt a good quality accounting practice in many companies. Brazil is already recognized worldwide for expertise in the Accounting field. Many scholars and professionals have contributed and keep working on this process.

However, it is crucial to extend this excellence to a larger number of Brazilian entities, including the government sector. The importance of accounting information as an element that generates trust within the economic system and a basis for reducing the risk of equity losses should be highlighted. The need of Accounting for society as a whole is undeniable and the appreciation of professionals will grow by improving the work quality. A relevant aspect is the existence of a platform so that the professional has safety and encouragement to evolve by using the concept of "Responsible Subjectivity" devised by professor Sérgio de Iudícibus. With the current speed of economic transactions, an important aspect, whose discussions should be expanded, is the fact that a company intends to pursue an operation and the theme has not been addressed, yet, by the accounting standards. In this field, scholars can greatly contribute by proposing alternative accounting approaches for new businesses. A huge effort for everyone is demonstrating that the set of Financial Statements provides information more complete and relevant than partial calculations or those based only on isolated flows.
We should recognize that the world is constantly changing and, as a consequence, the requirements, and we have to wake up every day with a new challenge, a new goal, and a growing and never-ending need for improvement, both personal and professional. Complexity and scope should be encouraging factors for our work. The academic world should continuously evaluate its work and check how it may be the major driving force for the improvement of Accounting and how to produce an effect on the practical field, by means of teaching and research. Again, we reiterate the need to encourage integration with the professional world, taking into account the great evolution that took place in recent years.

\section{REFERENCES}

Lopes, A. B. (2012). Contabilidade e finanças no Brasil. São Paulo: Atlas.

Martins, E.; Gelbcke, E. R. Santos, A.; Iudícibus, S. (2013). Manual de contabilidade societária. São Paulo: Atlas.

Iudícibus, S. (1977). Análise de balanços. São Paulo: Atlas.

Szuster, N.; Szuster, Fortunée R.; Szuster, Flávia R. (2015). Um novo instrumento para aplicação na contabilidade. Revista FIPECAFI, (3), 12-21. 